\title{
Die tema van God se spraak in Hebreërs se inleidingsformules
}

\begin{abstract}
Authors:
Albert J. Coetsee ${ }^{1}$

Gert J.C. Jordaan ${ }^{1}$

\section{Affiliations:}

${ }^{1}$ School for Ancient Language and Text Studies, North-West University, Potchefstroom

Campus, South Africa

\section{Correspondence to:}

Albert Coetsee

Email:

albertcoetsee@gmail.com

Postal address:

PO Box 24, Vermaas 2727,

South Africa

\section{Dates:}

Received: 26 June 2014

Accepted: 29 Oct. 2014

Published: 17 Mar. 2015

How to cite this article: Coetsee, A.J. \& Jordaan, G.J.C., 2015, 'Die tema van God se spraak in Hebreërs se inleidingsformules', In die Skriflig 49(1), Art. \#1852, 10 pages. $h$ ttp://dx.doi. org/10.4102/ids.v49i1.1852

\section{Copyright:}

(C) 2015. The Authors.

Licensee: AOSIS

OpenJournals. This work is licensed under the Creative Commons Attribution License.
\end{abstract}

\section{Read online:}

Scan this QR code with your smart phone or mobile device mobile device
to read online.
Alhoewel die voorkoms en gebruik van die Ou Testament in die meeste navorsing oor Hebreërs besonder baie aandag geniet, is dit nie die geval met die Hebreërskrywer se gebruik van inleidingsformules vir sy Ou-Testamentiese aanhalings nie. Die gevolg is dat daar tot op hede betreklik min selfstandige navorsing oor die Hebreërskrywer se tema van God se spraak by sy inleidingsformules gedoen is. In hierdie artikel word Hebreërs se inleidingsformules in besonderhede nagegaan om te bepaal wat die aard en inhoud van die Hebreërskrywer se verwysings na die tema van God se spraak in sy inleidingsformules is. Daar word onder andere bepaal dat Hebreërs 38 direkte aanhalings vanuit die Ou Testament bevat, dat die Hebreërskrywer, met slegs een uitsondering, elke inleidingsformule met 'n werkwoord van sê inlei, dat 'n Persoon van die Drie-eenheid in 34 van die 38 direkte aanhalings $( \pm 89 \%)$ die onderwerp en gevolglike Spreker van die Ou-Testamentiese woorde is, dat die Hebreërskrywer al drie Persone van die Drie-eenheid as God beskou, en dat die Hebreërskrywer oortuig is dat die Ou Testament geïnspireer is en God se geldige en relevante openbaring bly.

The theme of God's speech in Hebrews' introduction formulae. Whilst the occurance and function of the Old Testament in research on Hebrews enjoys a lot of attention, this is not the case for the writer of Hebrews' use of introduction formulae for his Old Testament quotations. The result is that up to date relatively few independent studies have been made on the writer of Hebrews' theme of God's speech in his introduction formulae. In this article the introduction formulae in Hebrews are researched in detail to determine the nature and content of the writer of Hebrews' reference to the theme of God's speech in his introduction formulae. Amongst other things it is determined that Hebrews has 38 direct quotations from the Old Testament, that with the exception of one introduction formula the writer of Hebrews introduces each direct quotation with a verb of saying, that a Person of the Trinity is the subject and consequential Speaker of the Old Testament words in 34 of the 38 direct quotations $( \pm 89 \%)$, that the writer of Hebrews views all three Persons of the Trinity as God, and that the writer of Hebrews is convinced that the Old Testament is divinely inspired and remains God's valid and relevant revelation.

\section{Inleiding}

Dit word universeel deur biblioloë aanvaar dat die Ou Testament die primêre grondslag van Hebreërs vorm. Elke hoofstuk van Hebreërs is met eksplisiete en implisiete verwysings na die Ou Testament deurdrenk. Die prominensie van die Ou Testament in Hebreërs het tot gevolg dat dit een van die grootste ondersoekvelde in navorsing oor Hebreërs is. Feitlik elke artikel, proefskrif en kommentaar oor Hebreërs neem deeglik van die prominente plek van die Ou Testament in Hebreërs kennis en verreken dit ook deeglik in die navorsing.

Alhoewel die voorkoms en gebruik van die Ou Testament in die meeste navorsing oor Hebreërs besonder baie aandag geniet, is dit nie die geval met die Hebreërskrywer se gebruik van inleidingsformules vir sy Ou-Testamentiese aanhalings nie. Hoewel die meeste navorsers van die Hebreërskrywer se (byna unieke) gebruik van inleidingsformules melding maak, bied slegs 'n handjievol van hulle meer uitgebreide navorsing oor hierdie onderwerp aan. ${ }^{1}$ Akademici is egter gou om te erken dat die inleidingsformules van die Nuwe-Testamentiese skrywers oor die algemeen belangrike inligting oor die outeur se gebruik en interpretasie van die Skrif bevat (Steyn 2011:24; vgl. Burns 1996:589, 597; Laughton 2005:vii). 1.Die belangrikste studie in hierdie verband is Laughton (2005) se verhandeling oor die inleidingsformules in Hebreërs. Naas sy werk is
Barth (1962:53-78) se artikel en dele van Schröger (1968:251-256) en Rascher (2007:31-44) se monografieë veral van belang. Ander artikels wat bietjie meer oor hierdie onderwerp uitbrei, is Burns (1996) en Peterson (2002:118-122). 
Die gevolg is dat daar tot op hede betreklik min selfstandige navorsing oor die Hebreërskrywer se tema van God se spraak in sy inleidingsformules gedoen is. Met die eerste oogopslag kom dit voor asof die Hebreërskrywer die meerderheid van sy Ou-Testamentiese aanhalings met 'n werkwoord van sê inlei, en in die meerderheid van hierdie gevalle 'n Persoon van die Drie-eenheid as onderwerp aandui.

Hierdie artikel poog om Hebreërs se inleidingsformules in besonderhede na te gaan om te bepaal wat die aard en inhoud van die Hebreërskrywer se verwysings na die tema van God se spraak by sy inleidingsformules is.

\section{Die aantal inleidingsformules in Hebreërs}

Om die inleidingsformules in Hebreërs in besonderhede na te gaan, moet eers bepaal word hoeveel inleidingsformules daar in Hebreërs is.

'n Inleidingsformule is enige woord of woordgroep waarmee 'n betrokke skrywer 'n direkte aanhaling inlei. Inleidingsformules in die Nuwe Testament lei in die meeste gevalle 'n Ou-Testamentiese aanhaling in (vgl. Laughton 2005:vii, 31). Dit kom ooreen met die taamlik wye voorkoms van inleidingsformules in antieke Judaïsme. Dit is gereeld gebruik om die gesag van die aanhalings aan te dui (Ellis 1991:79).

In die Nuwe Testament kom die aantal inleidingsformules per Nuwe-Testamentiese boek meermale met die aantal direkte aanhalings uit die $\mathrm{Ou}$ Testament in die betrokke boek ooreen. Om die aantal inleidingsformules in Hebreërs rofweg te bepaal, kan daar dus eenvoudig gekyk word na die aantal direkte Ou-Testamentiese aanhalings in Hebreërs. Tog verskil die mees prominente navorsers onder mekaar oor die

TABEL 1: Prominente navorsers se getal Ou-Testamentiese aanhalings in Hebreërs.

\begin{tabular}{lc}
\hline Prominente navorsers & Getal aanhalings \\
\hline Spicq (1952-1953:331) & 36 \\
Caird (1959:47) & 29 \\
Kistemaker (1961:16) & 32 \\
Barth (1962:54) & \pm 31 \\
Howard (1968:211) & 35 \\
Schröger (1968:251-252) & 35 \\
Westcott (1974:472) & 29 \\
Lane (1991:cxvi) & 31 \\
Ellingworth (1993:37) & 35 \\
Guthrie (1997:842) & \pm 36 \\
Longenecker (1999:147) & 38 \\
Koester (2001:116) & 35 \\
Johnson (2003:239) & 41 \\
Lewicki (2004:23) & 35 \\
Laughton (2005:36) & 39 \\
Karrer (2006:336) & \pm 35 \\
Steyn (2008:329) & 34 \\
Allen (2010:84) & 38 \\
Cockerill (2012:42) & 32 \\
\hline
\end{tabular}

presiese getal Ou-Testamentiese aanhalings in Hebreërs. Tabel 1 bied 'n illustrasie hiervan.

Soos uit die tabel blyk, kom die meeste navorsers by 'n getal tussen 29 en 38 uit (vgl. ook Combrink 1971:23). Dit laat iemand soos Schenck (2009:325) verklaar dat die getal direkte aanhalings in Hebreërs 'iewers' in die dertig is. ${ }^{2}$

Hierdie verskille onder navorsers kan hoofsaaklik aan twee verskynsels toegeskryf word, naamlik akademici wat verskillende kriteria gebruik waarvolgens hulle verwysings na die $\mathrm{Ou}$ Testament as direkte aanhalings kategoriseer (vgl. Guthrie 2003:272) en ook die verskeidenheid en vae wyse waarop die Hebreërskrywer na die Ou Testament verwys. Hierdie vae wyse van verwysing maak noukeurige kategorisering byna onmoontlik. Longenecker (1999:146) is byvoorbeeld van mening dat geen Nuwe-Testamentiese boek se Ou-Testamentiese aanhalings so moeilik is om te kategoriseer as juis dié in Hebreërs nie.

Vir die doeleindes van hierdie artikel is die volgende definisie van Nel (2004) gebruik om by 'n werkbare lys van direkte aanhalings in Hebreërs uit te kom:

'n Direkte aanhaling is ' $n$ aantal opeenvolgende woorde wat ' $n$ hoë graad van konformiteit met ('n) spesifieke Ou-Testamentiese vers(e) vertoon, gepaardgaande met een of ander inleidingsformule. (bl. 11)

Uit die aard van die saak was dit nie vir die Hebreërskrywer nodig om elke Ou-Testamentiese aanhaling met 'n inleidingsformule te begin nie. Tog maak die kriterium van ' $n$ gepaardgaande inleidingsformule in bostaande definisie dit baie makliker om direkte aanhalings van blote verwysings te onderskei. Hierdie kriterium word deur verskeie biblioloë as die basis vir onderskeid gevolg (vgl. Barth 1962:54; Cockerill 2012:4;2; Fitzmyer 1960-1961:300; Nel 2004:11-13; Peterson 2002:119; Steyn 1995:30).

Nadat Hebreërs deeglik op grond van bogenoemde kategorisering deurgegaan is, is bepaal dat Hebreërs 38 direkte aanhalings vanuit die Ou Testament bevat. Dit kan soos volg getabelleer word (Tabel 2) (vgl. Guthrie 1997:846849).

Alhoewel daar 38 direkte aanhalings van die Ou Testament in Hebreërs is, word daar nie 38 verskillende passasies aangehaal nie. 'n Aantal van hierdie aanhalings herhaal plekplek: Psalm 2:7 word twee keer aangehaal (1:5a; 5:5), Psalm 40:7-9 drie keer $(10: 5-7,8,9)$, Psalm 95:7b-11 vyf keer (3:7b$11,15 ; 4: 3,5,7)$, Psalm 110:4 drie keer $(5: 6 ; 7: 17,21)$ en Jeremia 31:31-34 twee keer $(8: 8-12 ; 10: 16-17)$. Dit beteken dat die 38 aanhalings uit $28 \mathrm{Ou}$-Testamentiese passasies bestaan (vgl. Cockerill 2012:42; Longenecker 1999:147; Peterson 2002:119). Aan die ander kant bestaan Hebreërs 10:37-38 se aanhaling uit 'n kombinasie van Jesaja 26:20 en Habakuk 2:3-4, wat

2.Die moeilikheidsgraad om die presiese getal direkte aanhalings in Hebreërs te bepaal, is duidelik te siene uit Guthrie se drie navorsingsartikels wat oor die loop van 'n dekade gepubliseer is en waarin hy sê dat Hebreërs 36 (1997:842), 35 (2003:274), of 37 (2007:919) direkte aanhalings bevat. 
TABEL 2: Direkte aanhalings uit die Ou Testament in Hebreërs.

\begin{tabular}{|c|c|c|}
\hline Nommer & Heb & Ou-Testamentiese teks \\
\hline 1 & $1: 5 a$ & Ps $2: 7$ \\
\hline 2 & $1: 5 b$ & 2 Sam 7:14 \\
\hline 3 & $1: 6$ & Deut 32:43b (LXX) \\
\hline 4 & $1: 7$ & Ps 104:4 (LXX 103:4) \\
\hline 5 & $1: 8-9$ & Ps 45:7-8 (LXX 44:7-8) \\
\hline 6 & 1:10-12 & Ps 102:26-28 (LXX 101:26-28) \\
\hline 7 & $1: 13$ & Ps 110:1 (LXX 109:1) \\
\hline 8 & $2: 6-8 a$ & Ps 8:5-7 \\
\hline 9 & $2: 12$ & Ps 22:23 (LXX 21:23) \\
\hline 10 & $2: 13 a$ & Jes 8:17 \\
\hline 11 & $2: 13 b$ & Jes 8:18 \\
\hline 12 & $3: 7 b-11$ & Ps 95:7b-1 (LXX 94:7b-11) \\
\hline 13 & $3: 15$ & Ps 95:7b-8 (LXX 94:7b-8) \\
\hline 14 & $4: 3$ & Ps 95:11 (LXX 94:11) \\
\hline 15 & $4: 4$ & Gen 2:2 \\
\hline 16 & $4: 5$ & Ps 95:11 (LXX 94:11) \\
\hline 17 & $4: 7$ & Ps 95:7b-8a (LXX 94:7b-8a) \\
\hline 18 & $5: 5$ & Ps $2: 7$ \\
\hline 19 & $5: 6$ & Ps 110:4 (LXX 109:4) \\
\hline 20 & $6: 14$ & Gen 22:17 \\
\hline 21 & $7: 17$ & Ps 110:4 (LXX 109:4) \\
\hline 22 & $7: 21$ & Ps 110:4 (LXX 109:4) \\
\hline 23 & $8: 5$ & Eks 25:40 \\
\hline 24 & $8: 8-12$ & Jer 31:31-34 (LXX 38:31-34) \\
\hline 25 & $9: 20$ & Eks $24: 8$ \\
\hline 26 & $10: 5-7$ & Ps 40:7-9 (LXX 39:7-9) \\
\hline 27 & $10: 8$ & Ps 40:7 (LXX 39:7) \\
\hline 28 & $10: 9$ & Ps 40:8-9 (LXX 39:8-9) \\
\hline 29 & $10: 16-17$ & Jer 31:33-34 (LXX 38:33-34) \\
\hline 30 & $10: 30 a$ & Deut 32:35a \\
\hline 31 & $10: 30 \mathrm{~b}$ & Deut 32:36a \\
\hline 32 & $10: 37-38$ & Jes $26: 20 \&$ Hab 2:3-4 \\
\hline 33 & $11: 18$ & Gen 21:12 \\
\hline 34 & $12: 5-6$ & Spr 3:11-12 \\
\hline 35 & $12: 21$ & Deut 9:19 \\
\hline 36 & $12: 26$ & Hag 2:6 \\
\hline 37 & $13: 5$ & Deut 31:6 \\
\hline 38 & $13: 6$ & Ps 118:6 (LXX 117:6) \\
\hline
\end{tabular}

beteken dat die Hebreërskrywer in totaal 29 verskillende OuTestamentiese passasies aanhaal.

Daar is ook bepaal dat, alhoewel Hebreërs 38 direkte aanhalings bevat, daar tegnies gesproke slegs 31

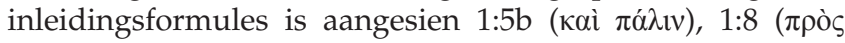

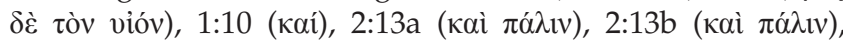

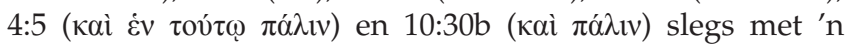
verbindingsfrase aan ' $n$ ander inleidingsformule gekoppel word. Gerieflikheidshalwe word daar dus binne Hebreërs se 38 direkte aanhalings tussen 31 inleidingsformules en 7 verbindingsfrases onderskei.

\section{'n Geheelbeeld van die inleidingsformules in Hebreërs}

Om die aard en inhoud van die inleidingsformules in Hebreërs te omskryf, is die volgende aspekte by elkeen van die 38 aanhalings se inleidingsformules bepaal:

- die werkwoordstam(me) wat gebruik is;

- die ontleding van die betrokke werkwoord(e) se tyd, modus en diatese;
- die grammatikale onderwerp van die werkwoord(e);

- die indirekte voorwerp van die werkwoord(e) (nl. aan wie die inhoud van die Ou-Testamentiese aanhaling gerig word); en

- die inhoud waaroor die Ou-Testamentiese aanhaling handel.

Bogenoemde data word hieronder saam bestudeer om by 'n geheeldbeeld van die aard en inhoud van die Hebreërskrywer se inleidingsformules te kom.

\section{'n Oorsig oor die inleidingsformules in Hebreërs}

Die bovermelde aspekte in Hebreërs se 31 inleidingsformules en 7 verbindingsfrases (in grys uitgelig) kan oorsigtelik soos volg getabelleer word (Tabel 3) (vgl. Laughton 2005:38-39, 49-50).

\section{Die werkwoorde van die inleidingsformules Die verskeie werkwoordstamme wat gebruik is}

Die onderskeie werkwoorde waarmee die Hebreërskrywer sy Ou-Testamentiese aanhalings inlei, asook hulle voorkoms in die inleidingsformules in Hebreërs, kan soos volg getabelleer word (Tabel 4$){ }^{3}$

Met die eerste oogopslag is dit duidelik dat ' $n$ vorm van die werkwoord, $\lambda \dot{\varepsilon} \gamma \omega$, in die meerderheid van die gevalle in Hebreërs se inleidingsformules voorkom. Hierdie werkwoord word in 25 van die Hebreërskrywer se 31 inleidingsformules gevind, wat beteken dat $\lambda \dot{\varepsilon} \gamma \omega$ in net bietjie meer as $80 \%$ van die skrywer se inleidingsformules voorkom. Opmerklik genoeg word elke verbindingsfrase $(1: 5 b, 8,10 ; 2: 13 a, 13 b ; 4: 5 ; 10: 30 b)$ aan 'n inleidingsformule gekoppel wat die werkwoord $\lambda \varepsilon \dot{\gamma} \omega$ bevat; dit beteken dat die werkwoord $\lambda \varepsilon ́ \gamma \omega$ implisiet by 32 van Hebreërs se $38 \mathrm{Ou}-$ Testamentiese aanhalings voorkom $( \pm 84 \%)$.

Wanneer bogenoemde nege werkwoorde se semantiese aanwending binne hulle onderskeie kontekste nagegaan word, is daar 'n verdere verskynsel wat uitstaan, naamlik dat elkeen van die nege werkwoorde wat in Hebreërs se inleidingsformules gebruik word om 'n Ou-Testamentiese aanhaling in te lei, telkens binne die semantiese domein 'kommunikasie' gebruik word (Louw \& Nida semantiese domein 33). Dit impliseer dat met die uitsondering van die inleidingsformule in Hebreërs 10:37, wat geen werkwoord bevat nie, ${ }^{4}$ elkeen van die oorblywende 30 inleidingsformules direk met 'n werkwoord van 'sê' ingelei word. Ook die sewe verbindingsfrases $(1: 5 b, 8,10 ; 2: 13 a$, $13 \mathrm{~b} ; 4: 5 ; 10: 30 \mathrm{~b})$ wat telkens aan 'n inleidingsformule gekoppel word wat die werkwoord $\lambda \dot{\varepsilon} \gamma \omega$ bevat, word indirek met 'n werkwoord van 'sê' ingelei. Dit beteken dat die Hebreërskrywer - met die uitsondering van Hebreërs 10:37 - nie één Ou-Testamentiese aanhaling sonder 'n werkwoord van 'sê' inlei nie.

3.Inleidingsformules waarin daar twee werkwoorde voorkom (meermale' $n$ indikatief gevolg deur die praesens partisipium $\lambda \dot{\varepsilon} \gamma(\omega v)$, word twee keer gelys, en is telkens met'n asterisk $(*)$ aangedui.

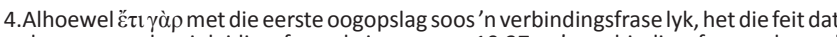
daar geen nabye inleidingsformule is waaraan 10:37 as 'n verbindingsfrase gekoppe kan word nie, tot gevolg dat hierdie frase as ' $n$ selfstandige inleidingsformule beskou moet word. 
TABEL 3: 'n Oorsig oor die inleidingsformules in Hebreërs.

\begin{tabular}{|c|c|c|c|c|c|c|}
\hline Nommer & Heb & Stam & Ontleding & Onderwerp & Indirekte voorwerp & Inhoud \\
\hline 1 & $1: 5 a$ & $\lambda \varepsilon^{\prime} \gamma \omega$ & Aor. Ind. Akt. & God & Die Seun & Seunskap \\
\hline 2 & $1: 5 b$ & - & - & God & Die Seun & Seunskap \\
\hline 3 & $1: 6$ & $\lambda \varepsilon ́ \gamma \omega$ & Praes. Ind. Akt. & God & Engele & Aanbidding van Seun \\
\hline 4 & $1: 7$ & $\lambda \varepsilon ́ \gamma \omega$ & Praes. Ind. Akt. & God & - & Engele as skepsels \\
\hline 5 & $1: 8$ & - & - & God & Die Seun & Seun se goddelikheid \\
\hline 6 & $1: 10$ & - & - & God & Die Seun & Seun se goddelikheid \\
\hline 7 & $1: 13$ & $\lambda \varepsilon ́ \gamma \omega$ & Perf .Ind. Akt. & God & Die Seun & Seun se verheerliking \\
\hline 8 & $2: 6$ & $\begin{array}{l}\delta 1 \alpha \mu \alpha \rho \tau \tau \dot{\rho} \rho \mu \alpha \iota l \\
\lambda \dot{\varepsilon} \gamma \omega\end{array}$ & $\begin{array}{l}\text { Aor. Ind. Med. } \\
\text { Praes. Part. Akt. }\end{array}$ & 'lemand' & God & Die mens se plek binne die skepping \\
\hline 9 & 2:11-12 & $\lambda \varepsilon^{\prime} \gamma \omega$ & Praes. Part. Akt. & Jesus & God & Seun se solidariteit \\
\hline 10 & $2: 13 a$ & - & - & Jesus & God & Seun se vertroue \\
\hline 11 & $2: 13 b$ & - & - & Jesus & God & Seun se solidariteit \\
\hline 12 & $3: 7$ & $\lambda \dot{\varepsilon}^{\prime} \gamma \omega$ & Praes. Ind. Akt. & Heilige Gees & Hoorders & Hoor God se stem! \\
\hline 13 & $3: 15$ & $\lambda \varepsilon^{\prime} \gamma \omega$ & Praes. Inf. Pass. & Heilige Gees & Hoorders & Hoor God se stem! \\
\hline 14 & $4: 3$ & $\lambda \dot{\varepsilon}^{\prime} \gamma \omega$ & Perf. Ind. Akt. & God & - & Sal nie rus ingaan! \\
\hline 15 & $4: 4$ & $\lambda \varepsilon^{\prime} \gamma \omega$ & Perf. Ind. Akt. & God & - & God se rus op 7 de dag \\
\hline 16 & $4: 5$ & - & - & God & - & Sal nie rus ingaan! \\
\hline 17 & $4: 7$ & $\begin{array}{l}\lambda \dot{\varepsilon} \gamma \omega \\
\pi \rho 0 \lambda \dot{\varepsilon} \gamma \omega\end{array}$ & $\begin{array}{l}\text { Praes. Part. Akt. } \\
\text { Perf. Ind. Pass. }\end{array}$ & God & - & Hoor God se stem! \\
\hline 18 & $5: 5$ & $\lambda \alpha \lambda \varepsilon^{\prime} \omega$ & Aor. Part. Akt. & God & Die Seun & Seunskap \\
\hline 19 & $5: 6$ & $\lambda \varepsilon^{\prime} \gamma \omega$ & Praes. Ind. Akt. & God & Die Seun & Seun se priesterskap \\
\hline 20 & 6:13-14 & $\begin{array}{l}\dot{o} \mu v v \dot{\omega} \omega \\
\lambda \dot{\varepsilon} \gamma \omega\end{array}$ & $\begin{array}{l}\text { Aor. Ind. Akt. } \\
\text { Praes. Part. Akt. }\end{array}$ & God & Abraham & Abraham se seën en nageslag \\
\hline 21 & $7: 17$ & $\mu \alpha \rho \tau \nu \rho \varepsilon ́ \omega$ & Praes. Ind. Pass & God & Die Seun & Seun se priesterskap \\
\hline 22 & $7: 21$ & $\lambda \dot{\varepsilon} \gamma \omega$ & Praes. Part. Akt. & God & Die Seun & Seun se priesterskap \\
\hline 23 & $8: 5$ & $\varphi \eta \mu i ́$ & Praes. Ind. Akt. & God & Moses & Bou van tabernakel \\
\hline 24 & $8: 8$ & 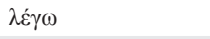 & Praes. Ind. Akt. & God & Die volk & Nuwe verbond \\
\hline 25 & $9: 19-20$ & 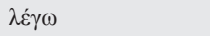 & Praes. Part. Akt. & Moses & Die volk & Bloed van verbond \\
\hline 26 & $10: 5$ & $\lambda \dot{\varepsilon} \gamma \omega$ & Praes. Ind. Akt. & Jesus & God & Seun se offer \\
\hline 27 & $10: 8$ & $\lambda \dot{\varepsilon} \gamma \omega$ & Praes. Part. Akt. & Jesus & God & Onvoldoende offers \\
\hline 28 & $10: 9$ & 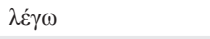 & Perf. Ind. Akt. & Jesus & God & Seun se offer \\
\hline 29 & $10: 15$ & $\mu \alpha \rho \tau v \rho \varepsilon ́ \omega \lambda \varepsilon^{\prime} \gamma \omega$ & $\begin{array}{l}\text { Praes. Ind. Akt. } \\
\text { Perf. Inf. Akt. }\end{array}$ & Heilige Gees & Skrywer en hoorders & Gerealiseerde nuwe verbond \\
\hline 30 & 10:30a & $\lambda \dot{\varepsilon} \gamma \omega$ & Aor. Part. Akt. & God & - & God se wraak \\
\hline 31 & $10: 30 b$ & - & - & God & - & God se oordeel \\
\hline 32 & $10: 37$ & - & - & God & Hoorders & Geloofs-volharding \\
\hline 33 & $11: 18$ & $\lambda \alpha \lambda \varepsilon^{\prime} \omega$ & Aor. Ind. Pass. & God & Abraham & Isak as nageslag \\
\hline 34 & $12: 5$ & $\delta 1 \alpha \lambda \dot{\varepsilon} \gamma о \mu \alpha \imath$ & Praes. Ind. Med. & God & Hoorders & Goddelike tugtiging \\
\hline 35 & $12: 21$ & $\lambda \varepsilon^{\prime} \gamma \omega$ & Aor. Ind. Akt. & Moses & - & Moses se vrees \\
\hline 36 & $12: 26$ & $\dot{\varepsilon} \pi \alpha \gamma \gamma \varepsilon \dot{\varepsilon} \lambda \lambda \mathrm{o} \mu \alpha \iota 1 \lambda \dot{\varepsilon} \gamma \omega$ & $\begin{array}{l}\text { Perf. Ind. Med. } \\
\text { Praes. Part. Akt. }\end{array}$ & God & - & Finale, eskatologiese oordeelsdag \\
\hline 37 & $13: 5$ & $\lambda \varepsilon^{\prime} \gamma \omega$ & Perf. Ind. Akt. & God & Hoorders & God se getrouheid \\
\hline 38 & $13: 6$ & $\lambda \dot{\varepsilon} \gamma \omega$ & Praes. Inf. Akt. & Skrywer en hoorders & God & God se bystand \\
\hline
\end{tabular}

TABEL 4: Werkwoordstamme in die inleidingsformules.

\begin{tabular}{|c|c|}
\hline Werkwoord & Voorkoms in Hebreërs \\
\hline$\overline{\lambda \dot{\varepsilon} \gamma \omega^{12}}$ & $\begin{array}{l}1: 5 a, 6,7,13 ; 2: 6^{*}, 11-12 ; 3: 7,15 ; 4: 3,4,7 * ; 5: 6 ; \\
6: 13-14^{*} ; 7: 21 ; 8: 8 ; 9: 19-20 ; 10: 5,8,9,15^{*}, 30 a ; 12: 21, \\
26^{*} ; 13: 5,6\end{array}$ \\
\hline$\delta 1 \alpha \mu \alpha \rho \tau \cup ́ \rho \circ \mu \alpha \imath$ & $2: 6^{*}$ \\
\hline$\pi \rho \circ \lambda \dot{\varepsilon} \gamma \omega$ & $4: 7^{*}$ \\
\hline$\lambda \alpha \lambda \dot{\varepsilon} \omega$ & $5: 5 ; 11: 18$ \\
\hline ỏ $\mu v v ́ \omega$ & $6: 13-14^{*}$ \\
\hline$\mu \alpha \rho \tau \nu \rho \varepsilon ́ \omega$ & $7: 17 ; 10: 15^{*}$ \\
\hline$\varphi \eta \mu i ́$ & $8: 5$ \\
\hline$\delta ı \alpha \lambda \varepsilon ́ \gamma о \mu \alpha \imath$ & $12: 5$ \\
\hline$\dot{\varepsilon} \pi \alpha \gamma \gamma \dot{\varepsilon} \lambda \lambda \lambda_{0} \mu \alpha$ & $12: 26^{*}$ \\
\hline
\end{tabular}

Hieruit is dit duidelik dat die Hebreërskrywer telkens die klem op die verbale aard van die $\mathrm{Ou}$ Testament laat val. Die Hebreërskrywer maak geen melding van $\gamma \rho \alpha ́ \varphi \omega$ nie - dus asof die Ou-Testamentiese woorde wat hy aanhaal, neergeskryf is.

\section{Die werkwoordtye en -modi}

Die werkwoordtye van die 30 inleidingsformules in Hebreërs word in Tabel 5 weergegee.

Met die eerste oogopslag is die Hebreërskrywer se voorkeur van die praesens bo enige ander werkwoordtyd in sy inleidingsformules duidelik (vgl. Barth 1962:59): 20 van sy 30 inleidingsformules bevat ' $n$ werkwoord in die praesens $(67 \%)$.

'n Blote tabel van die werkwoordtye van Hebreërs se inleidingsformules kan misleidend wees. Die primêre tye (praesens, aoristus, perfektum) moet dus binne hulle onderskeie kontekste nagegaan word vir die spesifieke nuanse van tyd (teenwoordige, toekomende en verlede tyd) wat elke inleidingsformule bevat. Samevattend blyk dit dat die 30 werkwoorde in die inleidingsformules in Hebreërs die volgende vier tydnuanses het: 
TABEL 5: Werkwoordtye van die inleidingsformules.

\begin{tabular}{ll}
\hline Tyd & Voorkoms in Hebreërs \\
\hline Praesens & $1: 6,7 ; 2: 6 *, 11-12 ; 3: 7,15 ; 4: 7^{*} ; 5: 6 ; 6: 13-14^{*} ; 7: 17,21 ;$ \\
& $8: 5,8 ; 9: 19-20 ; 10: 5,8,15^{*} ; 12: 5,26 * ; 13: 6$ \\
Aoristus & $1: 5 a ; 2: 6 * ; 5: 5 ; 6: 13-14^{*} ; 10: 30 a ; 11: 18 ; 12: 21$ \\
Perfektum & $1: 13 ; 4: 3,4,7 * ; 10: 9,15^{*} ; 12: 26^{*} ; 13: 5$ \\
\hline
\end{tabular}

- Agt inleidingsformules dui op 'n blote uitspraak in die verlede: 1:5a; 2:6; 5:5; 6:13-14; 9:19-20; 10:30a; 11:18; en 12:21.

- Agt inleidingsformules bevat 'n historiese praesens wat 'n uitspraak in die verlede lewendig in die hede voorstel: $1: 6,7 ; 2: 11-12 ; 5: 6 ; 7: 17 ; 8: 5 ; 8: 8 ; 10: 5$.

- Agt inleidingsformules dui op 'n uitspraak in die verlede waarvan die gevolge steeds in die hede voortduur: $1: 13$; $4: 3,4,7 ; 7: 21 ; 10: 8,9 ; 13: 5$.

- Ses inleidingsformules bevat ' $n$ uitspraak wat nou op die huidige oomblik gemaak word: $3: 7,15 ; 10: 15 ; 12: 5 ; 12: 26{ }^{5}$ 13:6.

Vanuit hierdie samevatting is dit duidelik dat die Hebreërskrywer ongeveer' $n$ kwart van sy Ou-Testamentiese aanhalings as blote uitsprake in die verlede inlei. Die oorgrote meerderheid van sy aanhalings dui hy deur die tyd van sy inleidingsformules aan as uitsprake in die verlede wat tans in die hede lewendig uitgedruk word as uitsprake waarvan die gevolge steeds in die hede voortduur - dus asof die uitsprake in die hede gemaak word. Die klem by die Hebreërskrywer se inleidingsformules is duidelik op die teenwoordige tyd.

Laastens is dit vanuit die onderskeie inleidingsformules ook duidelik dat die Hebreërskrywer die aktiewe diatese bo die passiewe verkies.

\section{Die grammatikale onderwerpe van die inleidingsformules}

\section{Die grammatikale onderwerpe in Hebreërs}

Die volgende Persone of persone is as die grammatikale onderwerpe van Hebreërs se inleidingsformules geïdentifiseer (vgl. Guthrie 2007:921; Laughton 2005:49-50; Lewicki 2004:23; Rascher 2007:37; Schröger 1968:252-254):

- God: In 20 van die 31 inleidingsformules (1:5a, 6, 7, 13; $4: 3,4,7 ; 5: 5,6$; 6:13-14; 7:17, 21; 8:5, 8; 10:30a, 37; 11:18; $12: 5,26 ; 13: 5)$ en in 5 van die 7 verbindingsfrases $(1: 5 b, 8$, $10 ; 4: 5 ; 10: 30 \mathrm{~b})$ is God die onderwerp van sê. Dit beteken dat die Hebreërskrywer 25 van sy 38 Ou-Testamentiese aanhalings inlei met God as onderwerp en Spreker $( \pm 66 \%$ of $2 / 3)$.

- Iemand: Hebreërs 2:6 bevat die enigste inleidingsformule wat Iemand $(\tau 1 \varsigma)$ as onderwerp het.

- Jesus: In vier van die 31 inleidingsformules (2:11-12; 10:5, $8,9)$ en in twee van die 7 verbindingsfrases $(2: 13 a, 13 b)$ is Jesus die onderwerp. Dit beteken dat die Hebreërskrywer ses van sy $38 \mathrm{Ou}$-Testamentiese aanhalings met Jesus as onderwerp en Spreker inlei ( $\pm 16 \%$ of $1 / 6)$.

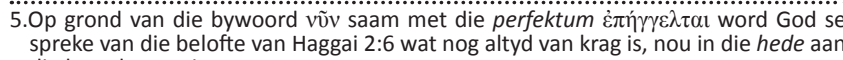
spreke van die belo
die hoorders gerig.
- Die Heilige Gees: In drie van die 31 inleidingsformules $\left(3: 7,15^{6} ; 10: 15\right)$ is die Heilige Gees die onderwerp. Dit beteken dat die Hebreërskrywer drie van sy $38 \mathrm{Ou}-$ Testamentiese aanhalings met die Heilige Gees as Spreker inlei $( \pm 8 \%)$.

- Moses: In twee gevalle is Moses die onderwerp (9:19-20; 12:21).

- Die skrywer en hoorders: Slegs die inleidingsformule in Hebreërs 13:6 het die skrywer en hoorders as onderwerp.

Rakende die tema van God se spraak is dit opvallend dat die Hebreërskrywer in 27 van sy 31 inleidingsformules en in al sewe sy verbindingsfrases óf God, óf Jesus, óf die Heilige Gees as onderwerp het. Dit beteken dat ' $n$ Persoon van die Drie-eenheid in 34 van die 38 direkte aanhalings in Hebreërs die onderwerp en gevolglike Spreker is $( \pm 89 \%)$. In teenstelling hiermee word menslike onderwerpe binne die inleidingsformules slegs vier keer aangetref (nl. iemand, ${ }^{7}$ Moses [2 keer] en die skrywer en hoorders). Hierdie verwysings bevat die enigste verwysing in Hebreërs na die outeur of bron van 'n Ou-Testamentiese aanhaling, naamlik die doelbewuste verwysing na Dawid in $4: 7^{8}$; die gedagte dat Dawid slegs die agent is deur wie God praat. Die Hebreërskrywer laat die klem duidelik op God val wat vanuit die Ou Testament praat.

Hierdie verskynsel noodsaak 'n vergelyking tussen die oorspronklike onderwerp van die Ou-Testamentiese aanhalings en die onderwerp wat die Hebreërskrywer in sy preek aan hierdie aanhalings toeken.

\section{Die oorspronklike onderwerpe in die Ou-Testamentiese tekste}

Eisenbaum (1997:92) beweer dat die meeste van die verse wat die Hebreërskrywer in die Ou Testament aanhaal as direkte rede voorkom. Dit sou beteken dat die meeste van die Hebreërskrywer se Ou-Testamentiese aanhalings die letterlike woorde van óf God, óf die profete, óf digters, óf een of ander persoon bevat.

'n Selfstandige studie oor die oorspronklike onderwerpe in die Ou-Testamentiese tekste wat in Hebreërs aangehaal word, bevestig Eisenbaum (1997) se bevinding. Die 38 direkte aanhalings in Hebreërs het in die Ou-Testamentiese teks oorspronklik die volgende grammatikale onderwerpe:

- Die HERE/God (21 keer): 1:5a; 5:5 (Ps 2:7); 1:5b (2 Sam 7:14); 1:13 (Ps 110:1); 3:7, 15; 4:3, 5, 7 (Ps 95:7b-11); 5:6;

6.Alhoewel öf die Heilige Gees, óf die Skrif as die geïmpliseerde onderwerp van $3: 15$ se inleidingsformule beskou kan word, maak die Hebreërskrywer se deurlopende beklemtoning dat God in en deur die Skrif praat, dit meer waarskynlik dat die Heilige Gees as die onderwerp bedoel word.

7.Dit lyk asof die Hebreërskrywer met sy verwysing na iemand doelbewus die menslike spreker verswyg om sodoende die klem op die verbale en geïnspireerde karakter van die Skrif te laat val, met God as die primêre Spreker (Guthrie 1997:842; 2003:274-275; vgl. Burns 1996:598; Lane 1991:46).

8.Dit blyk dat die skrywer doelbewus die naam van Dawid in Hebreërs 4:7 vermeld ter wille van sy argument van tydsverloop. Op grond van die eksegetiese tegniek genaamd 'die letterlike sin van 'n woord' (vgl. Guthrie 1997:844; 2003:282), argumenteer die skrywer dat die feit dat God soveel jare later by monde van Dawid steeds van rus praat, daarop dui dat Josua nie met die inname van Kanaän die tipe steeds van rus praat, daarop dui dat Josua nie met die inname van Kanaän die tipe
rus aan die volk gegee het wat hier beskrywe word nie (Lane 1991:100-101). God se belofte van rus is gevolglik steeds 'vandag' beskikbaar. 
7:17, 21 (Ps 110:4); 6:13-14 (Gen 22:17); 8:5 (Eks 25:40); 8:8; 10:15 (Jer 31:31-34); 10:30a (Deut 32:35a); 10:30b (Deut 32:36a); 10:37 (Jes 26:20, Hab 2:3-4); 11:18 (Gen 21:12); 12:26 (Hag 2:6).

- Moses (4 keer): 1:6 (Deut 32:43b); 9:19-20 (Eks 24:8); 12:21 (Deut 9:19); 13:5 (Deut 31:6).

- 'n Digter (10 keer): 1:7 (Ps 104:4); 1:8 (Ps 45:7-8); 1:10 (Ps 102:26-28); 2:6 (Ps 8:5-7); 2:11-12 (Ps 22:23); 10:5, 8, 9 (Ps 40:7-9); 12:5 (Spr 3:11-12); 13:6 (Ps 118:6).

- 'n Profeet (2 keer): 2:13a (Jes 8:17); 2:13b (Jes 8:18).

Uit hierdie navorsing is dit duidelik dat 37 van die 38 aanhalings inderdaad in die $\mathrm{Ou}$ Testament in die direkte rede voorkom. Die moontlikheid dat hierdie verskynsel aan toeval toegeskryf kan word, is weglaatbaar klein. Dit wil dus voorkom asof die Hebreërskrywer doelbewus OuTestamentiese aanhalings gekies het wat in die direkte rede bestaan.

Die enigste aanhaling wat nie in die Ou Testament in die direkte rede voorkom nie, is Hebreërs 4:4 se aanhaling van Genesis 2:2, wat ' $n$ narratief is. Tog is hierdie uitsondering ook geweldig insiggewend: deur die woorde van hierdie narratief in die mond van God te lê, sê die Hebreërskrywer by implikasie dat God ook spreek deur die gebeure wat in die $\mathrm{Ou}$ Testament opgeteken is. Dit kan as bevestiging beskou word dat die Hebreërskrywer van die goddelike inspirasie van die Ou-Testamentiese skrifte oortuig was.

'n Vergelyking tussen die oorspronklike Ou-Testamentiese onderwerp en die onderwerp by die Hebreërskrywer se direkte aanhalings word in Tabel 6 weergegee.

Alhoewel God as onderwerp van die direkte aanhalings in Hebreërs in die meeste gevalle ook die onderwerp van die betrokke woorde in die $\mathrm{Ou}$ Testament is, huiwer die Hebreërskrywer nie om die woorde van óf Moses, óf 'n digter, óf 'n verteller (Gen 2:2 in Heb 4:4) aan God toe te ken nie. Hiermee saam word die woorde van digters en profete uitsluitlik in die mond van Jesus gelê. Gevolglik kom dit voor asof die Hebreërskrywer nie in die eerste plek in die menslike skrywers geïnteresseerd is nie, maar hulle in sy inleidingsformules doelbewus vermy om die Ou Testament as die woorde van God, Jesus of die Heilige Gees aan te dui

TABEL 6: Ou-Testamentiese onderwerpe vs. die onderwerp by die Hebreërskrywer se direkte aanhalings.

\begin{tabular}{|c|c|c|}
\hline \multirow{2}{*}{$\begin{array}{l}\text { Onderwerp in Hebreërs } \\
\text { God ( } 25 \text { keer) }\end{array}$} & \multicolumn{2}{|c|}{ Onderwerp in die Ou Testament } \\
\hline & God (18 keer): & $\begin{array}{l}\text { 1:5a,5b, 13; 4:3, 5, 7; 5:5, } \\
6 ; 6: 13-14 ; 7: 17,21 ; 8: 5, \\
8 ; 10: 30 a, 30 b, 37 ; 11: 18 \\
12: 26\end{array}$ \\
\hline & Moses (2 keer): & $1: 6 ; 13: 5$ \\
\hline & Digter (4 keer): & $1: 7,8,10 ; 12: 5$ \\
\hline & Geen (1 keer): & $4: 4$ \\
\hline 'lemand’ (1 keer) & Digter (1 keer): & $2: 6$ \\
\hline \multirow[t]{2}{*}{ Jesus ( 6 keer) } & Digter (4 keer): & $2: 11-12 ; 10: 5$, \\
\hline & Profeet (2 keer): & $2: 13 a, 13 b$ \\
\hline Heilige Gees (3 keer) & God (3 keer): & $3: 7,15 ; 10: 15$ \\
\hline Moses (2 keer) & Moses (2 keer): & $9: 19-20 ; 12: 21$ \\
\hline Skrywer en hoorders (1 keer) & Digter (1 keer): & $13: 6$ \\
\hline
\end{tabular}

(vgl. Schröger 1968:253). Opmerklik genoeg, waar die Heilige Gees in die inleidingsformules as Spreker aangedui word, is die aanhaling uit die Ou Testament uitsluitlik God se woorde.

\section{Konklusie}

Die feit dat die Hebreërskrywer die oorgrote meerderheid van sy direkte aanhalings as die spraak van God inlei, het tot gevolg dat baie biblioloë verklaar dat dit die skrywer se oorkoepelende oortuiging is dat die hele Ou Testament uit die mond van God kom, en dat die Ou Testament God se geldige en relevante openbaring bly (vgl. Bruce 1990:27; Clements 1985:37; DeSilva 2000:32; Ellingworth 1993:37; Guthrie 1976:724; 1981:974; Isaacs 1992:68; Kistemaker 1984:5; Lane 1991:cxvii; Montefiore 1964:4; Peterson 2002:121; Schröger 1968:254; Vorster 1990:85). Vir die Hebreërskrywer lê die gesag van die bybelse teks by die eintlike Spreker van die Ou-Testamentiese woorde. Die aanhaling van Genesis 2:2 in Hebreërs 4:4 dui by uitstek op hierdie bevinding. Selfs die vier inleidingsformules in Hebreërs met menslike onderwerpe skep hoofsaaklik die indruk van goddelike openbaring, met die klem op die verbale karakter van die Skrif (vgl. veral Heb 2:6).

Dit lyk asof die Hebreërskrywer doelbewus Ou-Testamentiese aanhalings gekies het wat uit direkte rede bestaan om sodoende te beklemtoon dat God die betrokke woorde op die huidige oomblik aan die hoorders rig (vgl. Allen 2010:86; Cockerill 2012:44; Koester 2001:116). Die aanhalings in die direkte rede praat direk binne die nuwe konteks met dieselfde onmiddellike impak as wat dit in die oorspronklike konteks gehad het (Cortez 2008:102-103; Eisenbaum 1997:109). Eisenbaum (1997:111) praat van 'reused prophetic oracles'.

Die onderwerpe by die inleidingsformules dui ook iets van die Hebreërskrywer se prediking oor die Drie-eenheid aan. Die feit dat hy in sy inleidingsformules die gebruik van God, Jesus en die Heilige Gees afwissel, dui daarop dat hy al drie Persone as God beskou (vgl. Laughton 2005:51, 88). Dit word onder andere bevestig deur die feit dat die woorde wat die Heilige Gees sê $(3: 7,15)$, elders in Hebreërs (4:7) herhaal word as die woorde van God, en vice versa (vgl. 8:8 met 10:15; vgl. Peterson 2002:121; Rascher 2007:41; Schröger 1968:253). Die feit dat al drie die inleidingsformules met die Heilige Gees as onderwerp oorspronklik God as onderwerp in die $\mathrm{Ou}$ Testament het, dui verder daarop dat die Hebreërskrywer God en die Heilige Gees as 't ware as dieselfde Spreker sien (vgl. Schenck 2009:334-335). ${ }^{9}$

Laastens is dit opmerklik dat die enigste inleidingsformule met ons as onderwerp die heel laaste inleidingsformule in Hebreërs is (13:6). Dit wil voorkom asof die enigste gepaste reaksie van die skrywer en hoorders op al God se woorde sou wees om self te reageer met 'n aanhaling uit sy Woord (vgl. Allen 2010:86-87; Attridge 2004:212; Laughton 2005:54; Loane 1986:264).

9.Alhoewel dit nie 'n direkte aanhaling is nie, is ook Hebreërs $9: 8$ hier toepaslik waar die Heilige Gees 'n feit rakende die Ou Testament aan die hoorders 'duidelik

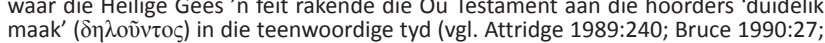
Schenck 2009:334). 


\section{Die indirekte voorwerpe in die inleidingsformules}

In aansluiting by die onderskeie grammatikale onderwerpe van die werkwoorde van 'sê' in Hebreërs word die indirekte voorwerpe, naamlik hulle aan wie die betrokke woorde gerig word, in Tabel 7 uiteengesit.

Wanneer die indirekte voorwerpe van die inleidingsformules spesifiek in die lig van die tema van God se spraak nagegaan word, is daar veral twee kardinale ondersoekvelde wat uitstaan: die dialoog tussen die Persone van die Drie-eenheid onderling, en die dialoog tussen die Persone van die Drieeenheid en die skrywer of die hoorders.

Wat die onderlinge dialoog tussen die Persone van die Drie-eenheid betref, kan die volgende bevestig word (vgl. Barth 1962:62; Laughton 2005:54; Lewicki 2004:39; Rascher 2007:37-41):

- God praat die meeste van die kere met die Seun (36\% van sy spraak is aan Hom gerig), maar nie een keer met die Heilige Gees nie;

- die Seun praat uitsluitlik met God; en

- die Heilige Gees praat nie met God óf die Seun nie.

Wat die dialoog tussen die Persone van die Drie-eenheid en die skrywer of die hoorders betref, is dit opmerklik dat:

- God af en toe met die skrywer of die hoorders praat (12\% van sy spraak is aan hulle gerig);

- die Seun glad nie met die skrywer of die hoorders praat nie;

- die Heilige Gees uitsluitlik met die skrywer of die hoorders praat; en

- die skrywer én die hoorders slegs één keer praat, en dan met God.

Wanneer hierdie twee ondersoekvelde gekombineer word, lyk dit soos volg:

- God praat dikwels met die Seun en af en toe met die skrywer of die hoorders;

TABEL 7: Indirekte voorwerpe in die inleidingsformules.

\begin{tabular}{lll}
\hline Onderwerp & Indirekte voorwerp & \\
\hline God (25 keer) & Die Seun (9 keer): & $1: 5 \mathrm{a}, 5 \mathrm{~b}, 8,10$, \\
& & $13 ; 5: 5,6 ; 7: 17$, \\
& Die engele (1 keer): & 21 \\
& Abraham (2 keer): & $6: 13-14 ; 11: 18$ \\
& Moses (1 keer): & $8: 5$ \\
& Die volk (1 keer): & $8: 8$ \\
& Die hoorders (3 keer): & $10: 37 ; 12: 5 ;$ \\
& & $13: 5$ \\
& Geen (8 keer): ${ }^{13}$ & $1: 7 ; 4: 3,4,5$, \\
& & $7 ; 10: 30 \mathrm{a}, 30 \mathrm{~b} ;$ \\
& & $12: 26$ \\
'lemand' (1 keer) & God (1 keer): & $2: 6$ \\
Jesus (6 keer) & God (6 keer): & $2: 11-12,13 \mathrm{a}$, \\
& & $13 \mathrm{~b} ; 10: 5,8,9$ \\
Heilige Gees (3 keer) & Die hoorders (2 keer): & $3: 7,15$ \\
& Skrywer én hoorders (1 keer): & $10: 15$ \\
Moses (2 keer) & Die volk (1 keer): & $9: 19-20$ \\
& Geen (1 keer): & $12: 21$ \\
Skrywer en hoorders (1 keer) & God (1 keer): & $13: 6$ \\
\hline
\end{tabular}

- die Seun praat uitsluitlik met God;

- die Heilige Gees praat uitsluitlik met die skrywer of die hoorders; en

- die skrywer én die hoorders praat uitsluitlik met God.

Vanuit hierdie bevindings kan die volgende konklusies getrek word:

- In Hebreërs is daar 'n dialoog tussen God en die Seun in die vorm van Ou-Testamentiese aanhalings. Dit lyk selfs asof die Hebreërskrywer die vreemde onderwerp, iemand $(\tau \iota \varsigma)$, by die inleidingsformule in 2:6 gebruik om nie die dialoog tussen die Vader en sy Seun (1:5-14; 2:11-13) te onderbreek nie (Cockerill 2012:127).

- Dit blyk dat die Heilige Gees se monoloog bedoel is om die woorde van God (onder andere die dialoog tussen God en die Seun) dinamies en relevant aan die hoorders in hulle konkrete situasie oor te dra (vgl. Hughes 1977:145; Schenck 2009:334).

- Die feit dat die enigste inleidingsformule wat ons as onderwerp het ook God as indirekte voorwerp bevat, het tot gevolg dat die aanname bevestig kan word dat die skrywer en hoorders op al God se woorde reageer deur self 'n aanhaling uit sy woord tot Hom te spreek.

Hierdie onderskeie dialoë lei Barth (1962:62) tot sy voorstel van Hebreërs se hermeneutiek as 'n dialogiese hermeneutiek. Hoewel hierdie voorstel van Barth waarskynlik oordrewe eensydig is, berus dit wel op 'n aanwysbare waarneming.

\section{Die inhoud van die inleidingsformules}

In die lig van die dialoog tussen God en die Seun, die dialoog tussen God en die skrywer of die hoorders en die monoloog van die Heilige Gees met die skrywer en die hoorders, is dit belangrik om te weet wat die inhoud van hierdie gesprekke is - naamlik dit waaroor hulle praat. Aan die hand van die onderskeie onderwerpe en indirekte voorwerpe word die inhoud van hierdie Ou-Testamentiese aanhalings in Tabel 8 uiteengesit.

TABEL 8: Die inhoud van die inleidingsformules.

\begin{tabular}{|c|c|c|}
\hline Onderwerp & Indirekte voorwerp & Inhoud \\
\hline \multirow[t]{2}{*}{ God } & Seun (9 keer) & $\begin{array}{l}\text { Sy Seunskap en sy Vader se Vaderskap } \\
\text { (1:5a, } 5 \text { b; } 5: 5) \text {. } \\
\text { Sy goddelikheid en ewige koningskap } \\
\text { (1:8). } \\
\text { Sy goddelikheid, ewigheid en } \\
\text { onveranderlikheid (1:10). } \\
\text { Sy verheerliking aan God se regterhand } \\
\text { (1:13). } \\
\text { Sy ewige priesterskap }(5: 6 ; 7: 17,21) \text {. }\end{array}$ \\
\hline & Hoorders ( 3 keer) & $\begin{array}{l}\text { Geloofsvolharding in die lig van die } \\
\text { wederkoms (10:37). } \\
\text { Goddelike tugtiging en dissiplinering } \\
\text { (12:5). } \\
\text { Sy getrouheid (13:5). }\end{array}$ \\
\hline Jesus & God (6 keer) & $\begin{array}{l}\text { Sy solidariteit met mense }(2: 11-12,13 b) \text {. } \\
\text { Sy vertroue op God ( } 2: 13 a) \text {. } \\
\text { Sy gewilligheid om sy liggaam as } \\
\text { voldoende offer te gee in kontras met die } \\
\text { Ou-Testamentiese offers }(10: 5,8,9) \text {. }\end{array}$ \\
\hline \multirow[t]{2}{*}{ Heilige Gees } & Hoorders (2 keer) & $\begin{array}{l}\text { Die opdrag om vandag na God se stem te } \\
\text { luister }(3: 7,15) \text {. }\end{array}$ \\
\hline & $\begin{array}{l}\text { Skrywer en hoorders } \\
\text { (1 keer) }\end{array}$ & $\begin{array}{l}\text { Die voortreflikheid van die gerealiseerde } \\
\text { nuwe verbond }(10: 15) \text {. }\end{array}$ \\
\hline $\begin{array}{l}\text { Skrywer, } \\
\text { hoorders } \\
\end{array}$ & God (1 keer) & God se bystand (13:6). \\
\hline
\end{tabular}


Wanneer hierdie gesprekke van nader beskou word, lewer dit baie insiggewende resultate op:

- By die dialoog tussen God en die Seun wat in Hebreërs aangehaal word, is dit opmerklik dat God se spreke met sy Seun uitsluitlik oor verklarings handel wat met sy verheerliking te make het: God verklaar Jesus as sy Seun en dat Hy sy Vader is (1:5a, 5b; 5:5); Hy verklaar sy Seun se goddelikheid, ewigheid en koningskap $(1: 8,10)$; Hy verklaar dat Hy sy Seun verheerlik het deur Hom uit te nooi om aan sy regterhand te kom sit (1:13); Hy verklaar sy Seun as ewige Hoëpriester $(5: 6 ; 7: 17,21)$. Hierteenoor handel die Seun se spreke met sy Vader uitsluitlik oor verklarings wat met sy vernedering te make het: die Seun verklaar sy solidariteit met mense op grond van sy menswording (2:11-12, 13b); Hy verklaar dat Hy as mens op God vertrou (2:13a); Hy verklaar sy gewilligheid om sy liggaam as voldoende offer te gee wat, in kontras met die herhaalde Ou-Testamentiese offers, die sonde effektief kon wegneem $(10: 5,8,9)$. Van nog nader beskou, is dit duidelik dat God die Seun met slegs een uitsondering deurlopend in die woorde van die Psalms toespreek (1:5a, $8,10,13 ; 5: 5,6 ; 7: 17,21),{ }^{10}$ en dat die Seun deurlopend met God in die woorde van die Psalms (2:11-12; 10:5, 8, 9) en die profetiese literatuur (2:13ab) praat.

- By die dialoog tussen God en die skrywer en die hoorders is dit opmerklik dat God hoofsaaklik met hulle praat oor die tipe geloofsvolharding wat Hy van hulle verwag. Hy verwag volharding in die geloof met die oog op die wederkoms (10:37), asook verdraagsaamheid tydens dissiplinering (12:5). Hiermee saam bevestig Hy ten slotte aan hulle dat Hy getrou is (13:5). Hierop reageer die skrywer en die hoorders deur teenoor God te bely dat hulle op Hom vertrou (13:6).

- In die Heilige Gees se monoloog met die skrywer en die hoorders is dit opmerklik dat Hy hulle oproep om vandag na God se stem te luister $(3: 7,15)$, en hulle oortuig van die voortreflikheid van die nuwe verbond wat Christus vir hulle laat realiseer het (10:15). Sodoende handel die Heilige Gees se monoloog met die skrywer en die hoorders telkens oor hulle verantwoordelikheid om korrek op God se voortreflike openbaring in Christus te reageer. ${ }^{11}$

\section{Samevatting en gevolgtrekking}

In hierdie artikel is die inleidingsformules in Hebreërs in besonderhede nagevors met die doel om daaruit die aard en inhoud van die Hebreërskrywer se verwysings na die tema van God se spraak by sy inleidingsformules te beskryf. Die data en konklusies kan soos volg saamgevat word:

- Algemeen: 'n Inleidingsformule is enige woord of woordgroep waarmee 'n betrokke skrywer 'n direkte aanhaling inlei. Op grond van hierdie studie se definisie

10.Die uitsondering is die aanhaling van 2 Samuel $7: 14$ (of 1 Kron 17:13) in Hebreërs $1: 5 \mathrm{~b}$. Tog is hierdie aanhaling eintlik ook 'n uitsondering, aangesien hierdie versinhoud meer profeties as histories van aard is (Ellingworth 1993:39).

11. Hiermee vertoon Hebreërs ' $n$ opvallende ooreenkoms met Jesus se belofte oor die parakletos in onder andere Johannes 14:25-26, 15:26-27 en 16:12-15. vir 'n direkte aanhaling is bepaal dat Hebreërs 38 direkte aanhalings bevat wat deur 31 inleidingsformules en 7 verbindingsfrases ingelei word.

- Werkwoordstamme: Al nege werkwoorde waarmee die Hebreërskrywer sy Ou-Testamentiese aanhalings inlei, word telkens binne die semantiese domein kommunikasie gebruik (Louw \& Nida, semantiese domein 33). Met die uitsondering van die inleidingsformule in Hebreërs 10:37 (wat geen werkwoord bevat nie) lei die Hebreërskrywer nie één Ou-Testamentiese aanhaling sonder'n werkwoord van 'sê' in nie. Die Hebreërskrywer laat telkens die klem op die verbale aard van die $\mathrm{Ou}$ Testament val.

- Grammatikale onderwerpe: God, Jesus en die Heilige Gees is in 34 van die 38 direkte aanhalings $( \pm 89 \%)$ die grammatikale onderwerp en gevolglike Spreker van die Ou-Testamentiese woorde (God is in $\pm 66 \%$ van die gevalle die onderwerp en Spreker, Jesus in $\pm 16 \%$ en die Heilige Gees in $\pm 8 \%$ ). In teenstelling hiermee word menslike onderwerpe slegs vier keer in die inleidingsformules aangetref. Dit is duidelik dat die Hebreërskrywer die klem op God laat val wat vanuit die Ou Testament praat.

- Werkwoordtye en -modi: Die Hebreërskrywer lei die oorgrote meerderheid $( \pm 73 \%)$ van sy aanhalings in as uitsprake in die verlede wat nou in die hede lewendig uitgedruk word as uitsprake waarvan die gevolge steeds in die hede voortduur, en as uitsprake wat nou op die huidige oomblik gemaak word. Die klem by die Hebreërskrywer se inleidingsformules val dus beslis op spraak in die teenwoordige tyd. God het in die verlede (aoristus) in die Ou Testament gespreek, maar vanuit die $\mathrm{Ou}$ Testament spreek Hy nou sodanig in die hede (praesens) dat die gevolg van daardie woorde van die $\mathrm{Ou}$ Testament in die nou 'n realiteit is (perfektum).

- Die Drie-eenheid: Die afwisseling tussen die verskillende Persone van die Drie-eenheid as onderwerpe vir die Hebreërskrywer se inleidingsformules maak dit moontlik om te bevestig dat hy al drie Persone as God verkondig. Dit word onder andere bevestig deur die feit dat die woorde wat die Heilige Gees in 3:7 en 3:15 sê in 4:7 as die woorde van God herhaal word, en die woorde van God in 8:8 dan in 10:15 as die woorde van die Heilige Gees herhaal word.

- Die inspirasie van die Ou Testament: Die feit dat die Hebreërskrywer soms die oorspronklike grammatikale onderwerp in die Ou-Testamentiese teks ignoreer en God, Jesus of die Heilige Gees as die nuwe Spreker van die betrokke Ou-Testamentiese woorde aandui, wys op sy oortuiging dat die $\mathrm{Ou}$ Testament geïnspireer is en uit God se mond kom, en dat dit God se geldige en relevante openbaring bly. In die besonder bevestig en beklemtoon die inleidingsformules in 2:6, 4:4 en 4:7 die Hebreërskrywer se handhawing van die geïnspireerde karakter van die Skrif, met God as die primêre Spreker. Vir die Hebreërskrywer en sy hoorders lê die gesag van die bybelse teks by die eintlike Spreker van die betrokke woorde. 
- Direkte rede: Dit blyk dat die Hebreërskrywer doelbewus verse wat in die $\mathrm{Ou}$ Testament in die direkte rede voorkom, aangehaal het (37 van die 38 aanhalings in Hebreërs volg hierdie patroon) juis om God se direkte spraak op die huidige oomblik in die hoorders se unieke situasie te beklemtoon. Die enigste uitsondering, naamlik die aanhaling van Genesis 2:2 in Hebreërs 4:4, bevestig die Hebreërskrywer se oortuiging van die goddelike inspirasie van die Skrif.

- Die dialoog tussen God en die Seun: Hebreërs bevat 'n deurlopende dialoog tussen God en die Seun in die vorm van Ou-Testamentiese aanhalings. God praat dikwels met die Seun, terwyl die Seun uitsluitlik met God praat. Dit is opmerklik dat God uitsluitlik met die Seun oor sy verheerliking praat, terwyl die Seun uitsluitlik met God oor sy vernedering praat. In die meeste gevalle praat God en die Seun met mekaar in die woorde van die Psalms.

- Die dialoog tussen God en die skrywer en die hoorders: God praat af en toe by wyse van Ou-Testamentiese aanhalings met die skrywer en die hoorders, terwyl die skrywer én die hoorders in hulle enkele OuTestamentiese aanhaling met God praat (13:6). God praat hoofsaaklik met die skrywer en die hoorders oor die tipe geloofsvolharding wat Hy van hulle verwag, terwyl die skrywer en die hoorders hierop met hulle belydenis reageer, naamlik dat hulle op God vertrou.

- Die monoloog van die Heilige Gees met die skrywer of die hoorders: In die drie Ou-Testamentiese aanhalings waarby die inleidingsformule die Heilige Gees as Spreker aandui, praat die Heilige Gees uitsluitlik met die skrywer of die hoorders, en dan uitsluitlik oor hulle verantwoordelikheid om korrek op God se voortreflike openbaring in Christus te reageer. Dit blyk dat die Heilige Gees se monoloog bedoel is om die woorde van God dinamies en relevant aan die hoorders in hulle konkrete situasie oor te dra.

- Hebreërs 13:6: Die finale inleidingsformule in Hebreërs is uniek, omdat dit die enigste inleidingsformule is waar die skrywer én die hoorders die onderwerp is. Dit kom voor asof die enigste gepaste reaksie van die skrywer én die hoorders op al God se woorde was om self 'n aanhaling uit sy woord tot Hom te spreek.

- God se spraak binne die Ou-Testamentiese aanhalings: Opmerklik genoeg het die Hebreërskrywer ook dikwels, waarskynlik doelbewus, sekere Ou-Testamentiese verse aangehaal wat inhoudelik met die tema van God se spraak te make het $(3: 7,10,11,15 ; 4: 3,7 ; 7: 21 ; 8: 8,9,10$; 10:7, 16).

Uit die manier waarop die Hebreërskrywer na God se spraak verwys, blyk dit dat hy oortuig is dat God die OuTestamentiese skrifte geïnspireer het. Juis omdat dit deur God geïspireer is, bly dit altyd-aktuele Godswoorde (Bateman 2010:53-54; Lewicki 2004:23). Wat God voorheen in die $\mathrm{Ou}$ Testament gesê het, sê Hy steeds met ewe veel gesag vandag. Gevolglik kon die Hebreërskrywer op grond van God se spraak in die Ou Testament sy hoorders met gesag opdragte vir die hede gee en hy kon dit gebruik om sy Christologiese veronderstellings te bevestig (vgl. Bateman 2010:32-36; Isaacs 1992:69). Indien 'n persoon vandag die Hebreërskrywer sou vra of God nog in die hede praat, sou hy sonder twyfel ja geantwoord het (Allen 2010:87; Johnson 2003:240-241; 2006:23). God praat vandag nog direk en dringend deur sy geskrewe woord.

\section{Erkenning Mededingende belange}

Die outeurs verklaar dat hulle geen finansiële of persoonlike verbintenis het met enige party wat hulle nadelig of voordelig kon beïnvloed het in die skryf van hierdie artikel nie

\section{Outeursbydrae}

Hierdie artikel is ' $\mathrm{n}$ redegering en verkorting van ' $\mathrm{n}$ hoofstuk van A.J.C. (2014) (Noordwes-Universiteit) se proefskrif, 'Die sprekende God in die boek Hebreërs: 'n openbaringshistoriese studie', wat onder leiding van G.J.C.J. (Noordwes-Universiteit) voltooi is.

\section{Literatuurverwysings}

Allen, D.L., 2010, Hebrews, Broadman \& Holman, Nashville. (The new American commentary, vol. 35).

Attridge, H.W., 1989, The epistle to the Hebrews: Hermeneia, Fortress, Philadelphia.

Attridge, H.W., 2004, 'The Psalms in Hebrews', in S. Moyise \& M.J.J. Menken (eds.), The Psalms in the New Testament, pp. 197-212, Clark, London.

Barth, M., 1962, 'The Old Testament in Hebrews: An essay in biblical hermeneutics', in W. Klassen \& G.F. Snyder (eds.), Current issues in New Testament interpretation: Essays in honor of O.A. Piper, pp. 53-78, Harper \& Row, New York.

Bateman, H.W., 2010, 'Second Temple exegetical pratices: Extra-biblical examples of exegesis compared with those in the book of Hebrews', Southwestern Journal of Theology 53(1), 26-54.

Bruce, F.F., 1990, The epistle to the Hebrews, Eerdmans, Grand Rapids. (The New International Commentary on the New Testament).

Burns, J.L., 1996, 'Hermeneutical issues and principles in Hebrews as exemplified in the second chapter', Journal of the Evangelical Theological Society 39(4), 587-607.

Caird, G.B., 1959, 'Exegetical method of the epistle to the Hebrews', Canadian Journal of Theology 5, 44-51.

Clements, R.E., 1985, 'The use of the Old Testament in Hebrews', Southwestern Journal of Theology 28, 36-45.

Cockerill, G.L., 2012, The epistle to the Hebrews, Eerdmans, Grand Rapids. (The New International Commentary on the New Testament).

Combrink, H.J.B., 1971, 'Some thoughts on the Old Testament citations in the epistle to the Hebrews', Neotestamentica 5, 22-36.

Cortez, F.H., 2008, "'See that you do not refuse the one who is speaking": Hearing God preach and obedience in the letter to the Hebrews', Journal of the Adventist Theological Society 19(1-2), 98-108.

Desilva, D.A., 2000, Perseverance in gratitude: A socio-rhetorical commentary on the epistle 'to the Hebrews', Eerdmans, Grand Rapids.

Eisenbaum, P.M., 1997, The Jewish heroes of Christian history: Hebrews 11 in literary context, Scholars Press, Atlanta. (Society of Biblical Literature Dissertation Series 156).

Ellingworth, P., 1993, The epistle to the Hebrews, Eerdmans, Grand Rapids. (The New International Greek Testament Commentary).

Ellis, E.E., 1991, The Old Testament in early Christianity: Canon and interpretation in the light of modern research, Mohr Siebeck, Tübingen.

Fitzmyer, J.A., 1960-1961, 'The use of explicit Old Testament quotations in Qumran literature and in the New Testament', New Testament Studies 7(4), 297-333. http://dx.doi.org/10.1017/S0028688500011838

Guthrie, D., 1976, New Testament introduction, 3rd rev. edn., InterVarsity, Leicester. Guthrie, D., 1981, New Testament theology, InterVarsity, Leicester.

Guthrie, G.H., 1997, 'Old Testament in Hebrews', in R.P. Martin \& P.H. Davids (eds.), Dictionary of the later New Testament and its developments, pp. 841-850, InterVarsity, Downers Grove. 
Guthrie, G.H., 2003, 'Hebrews' use of the Old Testament: recent trends in research', Currents in Biblical Research 1(2), 271-294. http://dx.doi. research', Currents in Biblical
org/10.1177/1476993X0300100208

Guthrie, G.H., 2007, 'Hebrews', in G.K. Beale \& D.A. Carson (eds.), Commentary on the New Testament Use of the Old Testament, pp. 919-995, Baker Academic, Grand Rapids.

Howard, G.E., 1968, 'Hebrews and the Old Testament quotations', Novum Testamentum 10, 208-216. http://dx.doi.org/10.2307/1560369

Hughes, P.E., 1977, A commentary on the epistle to the Hebrews, Eerdmans, Grand Rapids.

Isaacs, M.E., 1992, Sacred space: An approach to the theology of the epistle to the Hebrews, JSOT Press, Sheffield. (Journal for the Study of the New Testament Supplement Series 73).

Johnson, L.T., 2003, 'The scriptural world of Hebrews', Interpretation 57(3), 237-250. http://dx.doi.org/10.1177/002096430005700302

Johnson, L.T., 2006, Hebrews: A commentary, Westminster John Knox Press, Louisville. (The New Testament Library).

Karrer, M., 2006, 'The epistle to the Hebrews and the Septuagint', in W. Kraus \& R.G. Wooden (eds.), Septuagint research: Issues and challenges in the study of the Greek Jewish Scriptures, pp. 335-353, Society of Biblical Literature, Atlanta. (Society of biblical literature: Septuagint and cognate studies, 53).

Kistemaker, S.J., 1961, The Psalm citations in the epistle to the Hebrews, Van Soest, Amsterdam.

Kistemaker, S.J., 1984, Exposition of the epistle to the Hebrews, Baker Academic, Grand Rapids. (New Testament Commentary).

Koester, C.R., 2001, Hebrews: A new translation with introduction and commentary, Yale University Press, New Haven. (The Anchor Bible, vol. 36).

Lane, W.L., 1991, Hebrews 1-8, Thomas Nelson Publishers, Nashville. (Word biblical Commentary, vol. 47A)

Laughton, L.C., 2005, 'The hermeneutic of the author of Hebrews as manifest in the introductory formulae and its implications for modern hermeneutics', MA thesis, Faculty of Humanities, University of Pretoria.

Lewicki, T., 2004, 'Weist nicht ab den Sprechenden!': Wort Gottes und Paraklese im Hebräerbrief, Ferdinand Schöningh, Paderborn. (Paderbornes theologische Studien 41)
Loane, M.L., 1986, 'The unity of the Old and New Testaments as illustrated in the epistle to the Hebrews', in P.T. O'Brien \& D.G. Peterson (eds.), God who is rich in mercy: Essays presented to Dr. D.B. Knox, pp. 255-264, Lancer Books, Homebush mercy:
West.

Longenecker, R.N., 1999, Biblical exegesis in the apostolic period, 2nd edn., Eerdmans, Grand Rapids.

Louw, J.P. \& Nida, E.A. (eds.), 1996, Greek-English lexicon of the New Testament based on semantic domains, vol. 1, 2nd edn., United Bible Societies, New York.

Montefiore, H., 1964, A commentary on the epistle to the Hebrews, Adam \& Charles Black, London. (Black's New Testament Commentaries, vol. 19).

Nel, P., 2004, 'Die rol van Psalm 110 in Hebreërs', MA verhandeling, Skool vir Antieke Taal en Teksstudie, Noordwes-Universiteit, Potchefstroom

Peterson, D., 2002, 'God and Scripture in Hebrews', in P. Helm \& C.R. Trueman (eds.), The trustworthiness of God: Perspectives on the nature of Scripture, pp. 118-138, Eerdmans, Grand Rapids.

Rascher, A., 2007, Schriftauslegung und Christologie im Hebräerbrief, De Gruyter, Berlin. (Beihefte zur Zeitschrift für die neutestamentliche Wissenschaft 153).

Schenck, K.L., 2009, 'God has spoken: Hebrews' theology of the Scriptures', in R. Bauckham, D.R. Driver, T.A. Hart \& N. MacDonald (eds.), The epistle to the Hebrews and Christian theology, pp. 321-336, Eerdmans, Grand Rapids.

Schröger, F., 1968, Der Verfasser des Hebräerbriefes als Schriftausleger, Friedrich Pustet, Regensburg. (Biblische Untersuchungen 4).

Spicq, C., 1952-1953, L'Épître aux Hébreux, vol. 1, 2nd edn., Gabalda, Paris.

Steyn, G.J., 1995, Septuagint quotations in the context of the Petrine and Pauline speeches of the Acta Apostolorum, Kok, Kampen. (Contributions to Biblical Exegesis and Theology 12).

Steyn, G.J., 2008, 'An overview of the extent and diversity of methods utilised by the author of Hebrews when using the Old Testament', Neotestamentica 42(2), 327-352.

Steyn, G.J., 2011, A quest for the assumed LXX Vorlage of the explicit quotations in Hebrews, Vandenhoeck \& Ruprecht, Göttingen. (Forschungen zur Literatur des Alten und Neuen Testaments 235).

Vorster, W.S., 1990, 'Inleiding tot Hebreërs', in A.B. du Toit (red.), Handleiding by die Nuwe Testament, vol. 6, bl. 73-88, NG Kerkboekhandel, Pretoria.

Westcott, B.F., 1974, The epistle to the Hebrews: The Greek text with notes and essays, rev. edn., Eerdmans, Grand Rapids. 